\title{
Steviol, a natural product inhibits proliferation of the gastrointestinal cancer cells intensively
}

\author{
Junming Chen ${ }^{1,2}$, Yongmei Xiaa, ${ }^{1,2,3}$, Xiaochen Sui ${ }^{1,2}$, Qingrui Peng ${ }^{1,2}$, Tongtong \\ Zhang ${ }^{1,2}$, Jian $\mathrm{Li}^{4}$ and Jue Zhang ${ }^{4}$ \\ ${ }^{1}$ State Key Laboratory of Food Science and Technology, Jiangnan University, Wuxi, Jiangsu 214122, China \\ ${ }^{2}$ Key Laboratory of Synthetic and Biological Colloids (Ministry of Education), School of Chemical and Materials Engineering, \\ Jiangnan University, Wuxi, Jiangsu 214122, China \\ ${ }^{3}$ International Joint Laboratory on Food Safety, Jiangnan University, Wuxi, Jiangsu 214122, China \\ ${ }^{4}$ Key Laboratory of Nuclear Medicine of Ministry of Health, Jiangsu Institute of Nuclear Medicine, Wuxi, Jiangsu 214063, \\ China
}

Correspondence to: Yongmei Xia, email: ymxia@jiangnan.edu.cn

Keywords: steviol; steviol glycoside; cancer; gastrointestinal

Received: September 13, $2017 \quad$ Accepted: March 24, $2018 \quad$ Published: May 29, 2018

Copyright: Chen et al. This is an open-access article distributed under the terms of the Creative Commons Attribution License 3.0 (CC BY 3.0), which permits unrestricted use, distribution, and reproduction in any medium, provided the original author and source are credited.

\section{ABSTRACT}

New anticancer agents with lower toxicity have been always urged because of drug resistance associated with overused chemotherapy agents. In this study, steviol, a colonic metabolite of natural sweetener and also a component in leaves of stevia rebaudiana bertoni, was found to possess intensive anticancer activity on the human gastrointestinal cancer cells. Steviol inhibited six human gastrointestinal cancer cells intensively as 5-fluorouracil did at $100 \mu \mathrm{g} / \mathrm{mL}$. The inhibition mechanism follows mitochondrial apoptotic pathway that was evidenced by increase of $\mathrm{Bax} / \mathrm{Bcl}-2$ ratio, activation of p21 and p53; and caspase 3-independent mechanism was also involved. These results are consistent with the miRNA expression analysis. The most regulated miRNAs in the steviol treated gastrointestinal cancer cells were miR-203a-3p $(\log 2$ $=1.32)$ and $\mathrm{miR}-6088(\log 2=-2.54)$ in HCT-116, $\mathrm{miR}-1268 \mathrm{~b}(\log 2=19.85)$ and $\mathrm{miR}-$ $23 \mathrm{c}(\log 2=-2.05)$ in $\mathrm{MKN}-45$. In view of the metabolic characteristics of steviol and its cytotoxicity on the cancer cells, steviol could be a chemotherapy agent potentially for cancer treatment.

\section{INTRODUCTION}

Cancer has become the leading cause of mortality for Chinese population, with 4.3 million newly diagnosed cancer patients and 2.8 million deaths in 2013 [1,2], but cancer incidence is still increasing rapidly, esspecially for gastrointestinal cancers.

Most treatments on gastrointestinal cancers execute chemotherapy either before or after surgery. The anticancer drugs, such as docetaxel, doxorubicin (DOX), 5-fluorouracil (5-FU), and cisplatin (diammine dichloroplatinum (II), CDDP), have drawbacks of nonspecificity, drug resistance, and toxicity on normal cells. To overcome these limitations, either new drug discovery or combinatorial chemotherapy urges finding competitive anticancer agents.

Steviol, a rare component in leaves of stevia rebaudiana bertoni, is also the only colonic metabolite of steviol glycosides - a family of natural sweeteners. To date, about 40 steviol glycosides have been discovered in leaves of stevia rebaudiana bertoni; most of them share a similar metabolism pathway in human gastrointestinal tract [3]. The steviol glycosides are not digested until they reach colon where they are hydrolyzed to steviol. Thereafter, falling in enterohepatic circulation, some steviol is absorbed in the colon and then glucuronated in the liver; while the rest steviol is found in feces $[4,5]$. 
So far, few reports have been found regarding the cytotoxicity of steviol on human cells. Previously, we reported that steviol presented competitive anticancer activity on U2OS cells [6]. Comparing to 5-FU (LD 50 of $115 \mathrm{mg} / \mathrm{kg}$, oral, mouse) and DOX (LD 50 of $14 \mathrm{mg}$ / $\mathrm{kg}$, oral, mouse), steviol possess a much higher LD 50 of $15 \mathrm{~g} / \mathrm{kg} \mathrm{BW}$ in rats and mice (both sexes) [7] and a ADI of $4 \mathrm{mg} / \mathrm{kg} \mathrm{BW/day} \mathrm{[8].} \mathrm{During} \mathrm{the} \mathrm{metabolism} \mathrm{of}$ steviol or steviol glycosides, steviol cannot be detected in the blood and its duration in human body is much longer than that of 5-FU and DOX. Therefore, if steviol presented anticancer activity on more cancer species, it may be served as a potential chemotherapy agent for cancer treatment; moreover, steviol glycosides could be found themselves used in targeting chemotherapy agent rather than as a natural sweetener. Thus, in this study, the in vitro anti-proliferation of steviol on the human gastrointestinal cancer cells were investigated, and the mechanism was studied with expression analysis on the relative proteins and miRNA.

\section{RESULTS AND DISCUSSION}

\section{Inhibition of steviol on viability of the gastrointestinal cancer cells}

Six human gastrointestinal cell lines were tested with steviol treatment. For comparison, 5-FU was used as the positive control. Figure 1 indicates that steviol inhibited the cells viability in a time and dose-dependent manner. With same dosage (100-200 $\mu \mathrm{g} / \mathrm{mL})$, steviol presented a similar inhibition efficiency as 5-FU did on all assayed cancer cells; at $250 \mu \mathrm{g} / \mathrm{mL}$, steviol even performed stronger inhibition. Considering that steviol possess a LD 50 value of 130 times higher than that of $5-\mathrm{FU}$, this is a remarkable performance indeed.

\section{Steviol causes phase arrest and apoptosis of the gastrointestinal cancer cells}

Many anticancer agents inhibit cancer cells via cell phase arrest and cell apoptosis pathway. Exposure to 1000 $\mathrm{ng} / \mathrm{ml}$ of 5-FU in SW480 and COLO320DM resulted in G1S-phase arrest and induction of apoptosis [9]. 5-FU induced apoptosis of the gastric cancer cells, and up-regulated Bax/ Bcl-2 ratio in MKN-74 and MKN-45 cell lines [10, 11]. Low-dose cisplatin induced a transient G1-S phase arrest and apoptosis in HepG2 by down-regulation of p27KIP1 and Bcl-xL [12]. Similarly, as Figure 2 and Table 1 indicated, steviol also caused cell phase arrest and apoptosis. Specifically, steviol treatment caused G1 arrest on Caco2, HCT-116, MKN-45 and HGC-27, G2 arrest on HCT-8 and MGC-803, respectively. Therefore, HCT-116, MKN45 were selected as representative of gastric and colonic cancer cells, respectively, for subsequent experiments on cell apoptosis and miRNA analysis thereafter.
The results from Hoechst staining (Figure 3A), JC-1 staining (Figure 3B), and Annexin V-FITC/PI doublelabeled flow cytometry (Figure 3C, 3D) indicate a cell apoptosis in concentration dependent. These results further elucidate that steviol inhibits viability of HCT-116, MKN45 cells through arresting the G1 phase of cell cycle, and stimulating the apoptosis progress.

Subsequently, to understand the underlining mechanism of cell cycle regulation induced by steviol, the cell cycle and apoptosis related proteins were examined in following experiment.

\section{Apoptotic pathway}

First, to investigate the mechanism of steviolmediated phase arrest, we assessed the phase regulation related proteins including p21, p53 and Cyclin D1. As shown in Figure 4, the expression of p21 and p53 were up-regulated, whereas Cyclin D1 was down-regulated; and all of the regulations were concentration dependent.

Subsequently, the apoptosis related proteins Bcl-2, Bax and Caspase 3 in steviol treated cancer cells were detected using Western blotting (Figure 4). It reveals that the ratio of Bax/Bcl-2 was up-regulated with increasing concentration of steviol, indicating a mitochondrial apoptotic pathway [13].

Taking together, steviol has a wide-spectrum inhibitory activity on the human gastrointestinal cancer cells through leading a mitochondrial apoptotic pathway as evidenced by increase of the Bax/Bcl-2 ratio, activation of $\mathrm{p} 21$, $\mathrm{p} 53$; whereas Caspase 3-independent mechanism was involved.

\section{miRNA regulation on the gastrointestinal cancer cells exposed to steviol}

MicroRNAs are specific for multiple cellular functions, including cell generation, differentiation, multiplication, carcinogenesis, and apoptosis. miRNAs regulation is critically involved in the development and progression of cancer [14-16]. Restoration or repression of miRNAs' expression and activity shows high potential in managing cancer, and many studies on pre-clinical models have demonstrated the feasibility and efficacy of miRNA-based therapy [17].

To obtain comprehensive information of miRNA differential expression, human miRNA-based array layout was chosen and designed to verify the miRNA differential expression of steviol treated HCT-116 and MKN-45 cells (see also Supplementary Tables 1 and 2). As presented in Supplementary Tables 1 and 2, steviol treated cells exhibited different miRNA regulation, the most regulated as like miR-203a-3p $(\log 2=1.32)$ and miR$6088(\log 2=-2.54)$ in HCT-116, miR-1268b $(\log 2=19.85)$ and $\mathrm{miR}-23 \mathrm{c}(\log 2=-2.05)$ in MKN-45. And the target gene possibly included TP53INP1 (tumor protein p53 inducible nuclear protein 1), TNFSF15 (tumor necrosis 

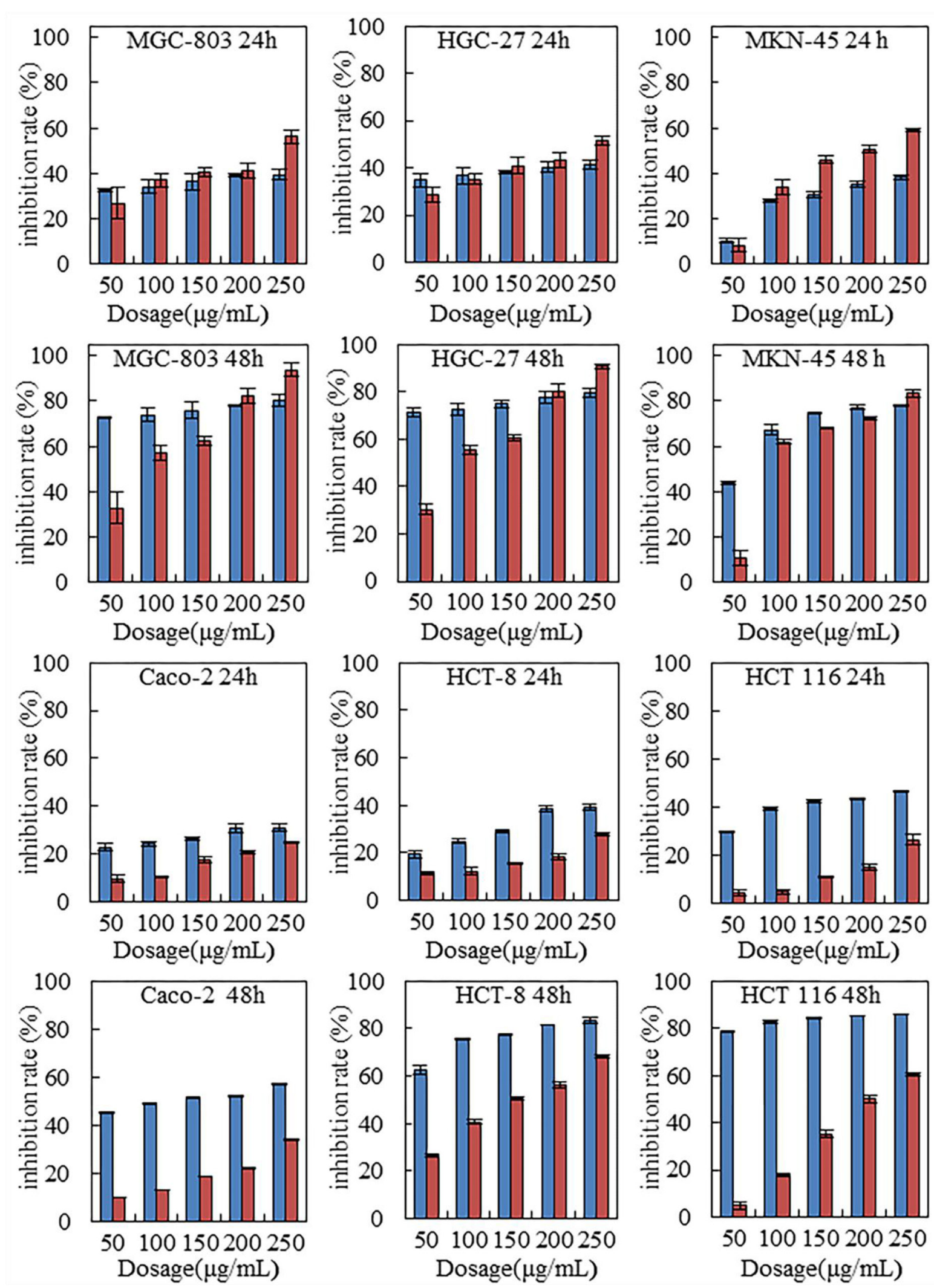

Figure 1: Steviol inhibited proliferation of the human gastrointestinal cancer cells. 
Table 1: Effect of steviol on cell cycle progression of the gastrointestinal cancer cells

\begin{tabular}{|c|c|c|c|c|}
\hline Cell & Dosage $(\mu \mathrm{g} / \mathrm{mL})$ & G1 (\%) & $\mathrm{S}(\%)$ & G2 (\%) \\
\hline \multirow{3}{*}{ Caco-2 } & Control & 62.55 & 32.69 & 4.77 \\
\hline & 100 & 65.69 & 29.39 & 4.91 \\
\hline & 200 & 70.89 & 21.22 & 8.00 \\
\hline \multirow{3}{*}{ HCT-8 } & Control & 73.05 & 24.41 & 2.55 \\
\hline & 100 & 71.69 & 23.32 & 4.99 \\
\hline & 200 & 81.94 & 10.06 & 8.00 \\
\hline \multirow{3}{*}{ НCТ-116 } & Control & 57.43 & 34.57 & 8.00 \\
\hline & 100 & 65.51 & 26.49 & 8.00 \\
\hline & 200 & 67.39 & 25.15 & 7.46 \\
\hline \multirow{3}{*}{ MKN-45 } & Control & 57.43 & 34.57 & 8.00 \\
\hline & 100 & 62.55 & 32.69 & 4.77 \\
\hline & 200 & 70.89 & 21.22 & 8.00 \\
\hline \multirow{3}{*}{ MGC-803 } & Control & 67.66 & 24.40 & 7.95 \\
\hline & 100 & 63.71 & 24.57 & 11.72 \\
\hline & 200 & 59.28 & 27.81 & 12.62 \\
\hline \multirow{3}{*}{ HGC-27 } & Control & 45.05 & 43.81 & 11.15 \\
\hline & 100 & 52.87 & 40.02 & 7.11 \\
\hline & 200 & 57.89 & 31.04 & 11.07 \\
\hline
\end{tabular}

factor (ligand) superfamily, member 15) and TPD52 (tumor protein D52) for miR-203a-3p; TNFRSF11A (tumor necrosis factor receptor superfamily, member 11a, NFKB activator) for miR-6088; TUSC1 (tumor suppressor candidate 1), ZNF (zinc finger protein) and TP73 (tumor protein p73) for miR-1268b;WT1 (Wilms tumor 1), TPD52 (tumor protein D52), ST7L (suppression of tumorigenicity 7 like) and TUSC2 (tumor suppressor candidate 2) for miR-23c [18-22].

Other miRNAs regulations on the gastrointestinal cancer cells reported in literatures are summarized in Table 2 for comparison and discussion. For example,
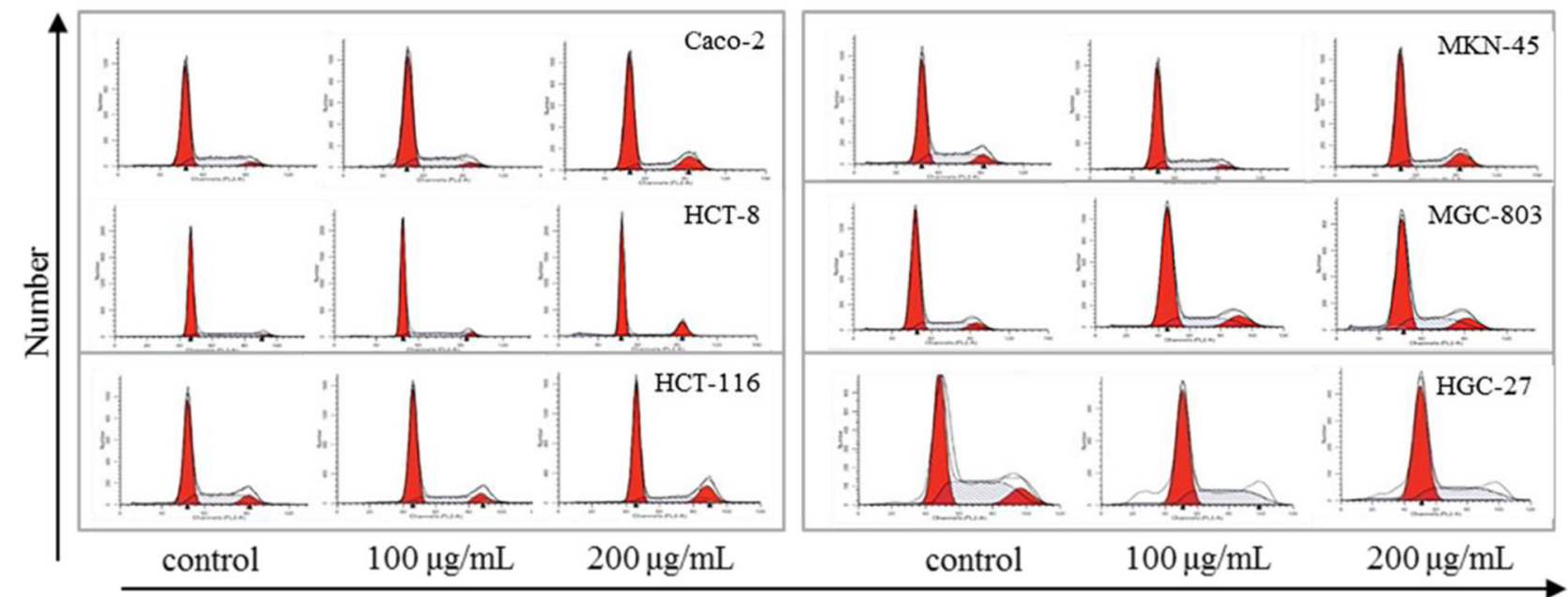

Channels (FL2-A)

Figure 2: Effect of steviol on cell cycle distribution in the human gastrointestinal cancer cells. 

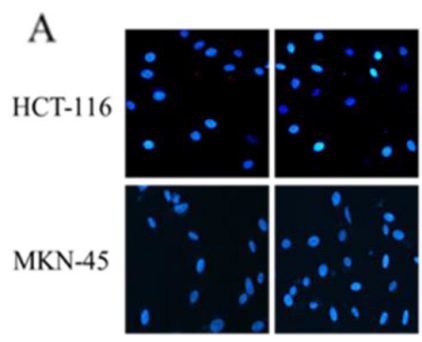

$\mathrm{C}$
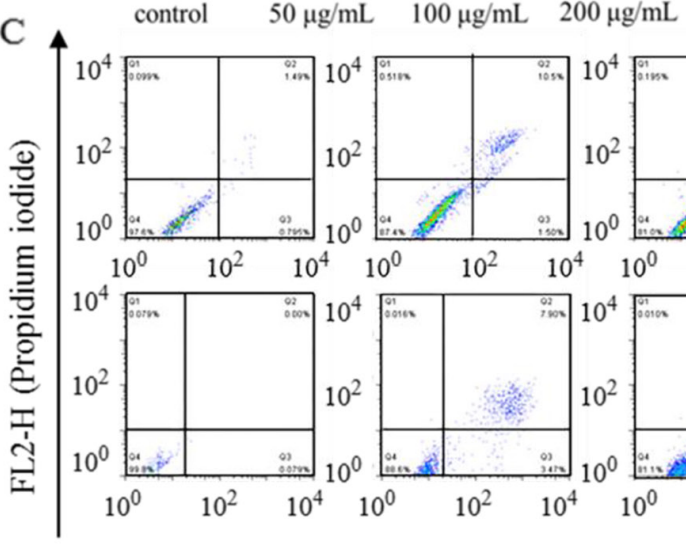

control

$100 \mu \mathrm{g} / \mathrm{mL}$

FL1-H (Annexin V-PI)

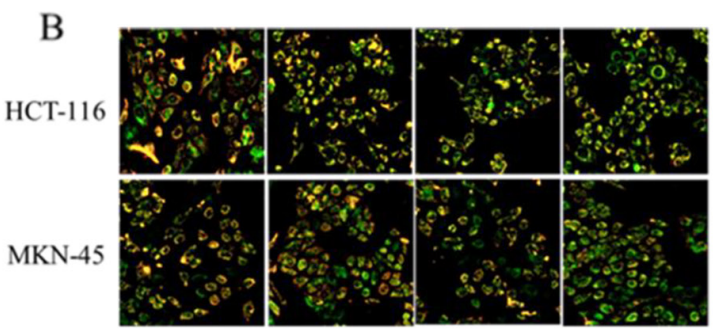

control $\quad 50 \mu \mathrm{g} / \mathrm{mL} \quad 100 \mu \mathrm{g} / \mathrm{mL} \quad 200 \mu \mathrm{g} / \mathrm{mL}$

$\mathrm{D}$
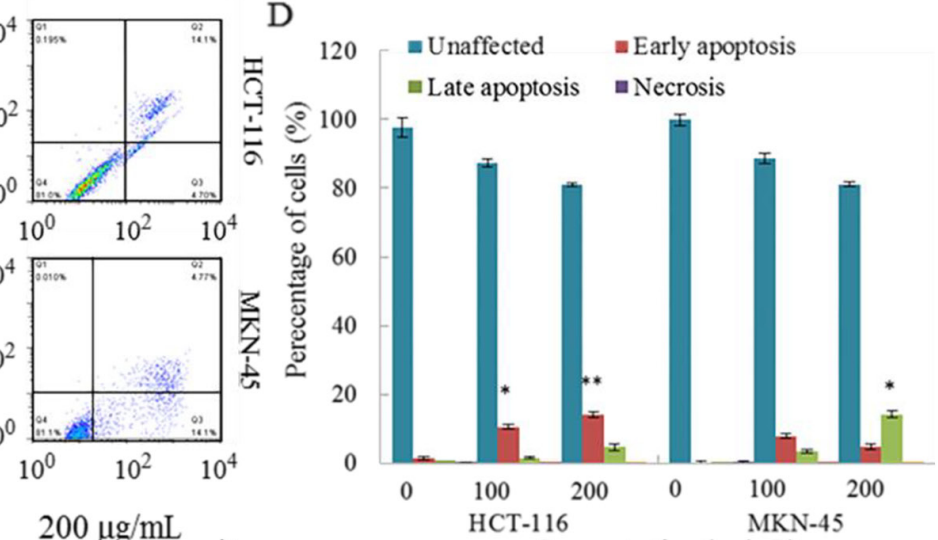

Concentration $(\mu \mathrm{g} / \mathrm{mL})$

Figure 3: Steviol induced apoptosis of the cancer cells. (A) Photomicrographs of Hoechst 33342. (B) Effect of steviol on mitochondrial membrane potential $(\Delta \Psi \mathrm{m})$ in the cancer cells. (C, D) the cancer cells were treated with steviol for $48 \mathrm{~h}$ and stained with Annexin V - PI. ${ }^{*} \mathrm{p}<0.05,{ }^{* *} \mathrm{p}<0.01$.

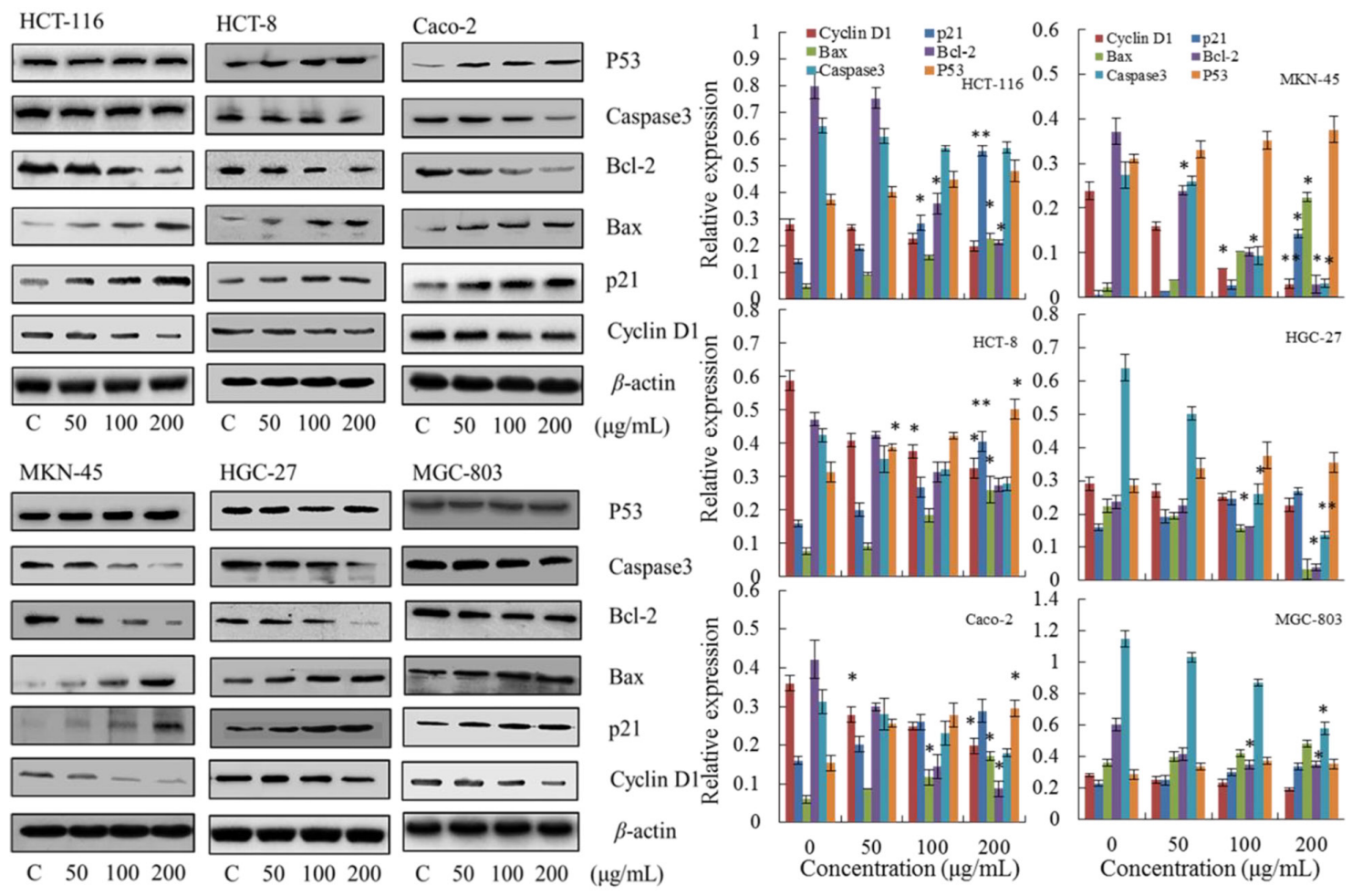

Figure 4: Effect of steviol on protein expression of the cell cycle and apoptosis. $\beta$-actin was used as an internal control. ${ }^{*} \mathrm{p}<0.05$, ${ }^{* *} \mathrm{p}<0.01$. 
Table 2: miRNAs in the gastrointestinal cancer cells presented significant differential expression

\begin{tabular}{|c|c|c|c|c|}
\hline miRNA & Source & Regulation & Drug & $\begin{array}{l}\text { Reference and function suggested } \\
\text { if any }\end{array}$ \\
\hline miR-663a & HCT-116 cells & upregulated & AMPs & $\begin{array}{l}\text { miR- } 663 \text { a regulates growth of colon } \\
\text { cancer cells, after administration of } \\
\text { antimicrobial peptides, by targeting } \\
\text { CXCR4-p21 pathway [31] }\end{array}$ \\
\hline miR-409-3p & $\begin{array}{l}\text { HCT } 116, \text { DLD-1, } \\
\text { SW480, HT-29 }\end{array}$ & upregulated & oxaliplatin & $\begin{array}{l}\text { miR-409-3p is capable of enhancing } \\
\text { the chemosensitivity of colon } \\
\text { cancer cells by inhibiting Beclin-1- } \\
\text { mediated autophagy [33] }\end{array}$ \\
\hline $\begin{array}{l}\text { miR-3142 } \\
\text { miR-1290 } \\
\text { miR-20a } \\
\text { miR-4301 } \\
\text { miR-4286 } \\
\text { miR-3182 } \\
\text { miR-3142 } \\
\text { miR-1246 } \\
\text { miR-720 }\end{array}$ & Сaco-2, HRT-18 & $\begin{array}{c}\text { upregulated } \\
\text { downregulated }\end{array}$ & Sorafenib & {$[34]$} \\
\hline miR-181c & KATO-III, MKN-45 & upregulated & Iodine-125 irradiation & {$[35]$} \\
\hline $\begin{array}{l}\text { miR-199a-3p } \\
\text { miR-21 } \\
\text { miR-223 } \\
\text { miR-342-3p } \\
\text { miR-126 } \\
\text { miR-146b-5p } \\
\text { miR-1978 } \\
\text { miR-711 } \\
\text { miR-1280 }\end{array}$ & $\begin{array}{l}\text { MKN-1, MKN-45, } \\
\text { MKN-74 }\end{array}$ & $\begin{array}{c}\text { upregulated } \\
\text { downregulated }\end{array}$ & Metformin & $\begin{array}{l}\text { Metformin blocked the cell cycle in } \\
\mathrm{G}(0)-\mathrm{G}(1) \text { in vitro and in vivo. This } \\
\text { blockade was accompanied by a } \\
\text { strong decrease of } \mathrm{G}(1) \text { cyclins [36]. }\end{array}$ \\
\hline
\end{tabular}

miR-146a-5P $(\log 2=1.88)$ has a critical role in the process of AIPC prostate cancer cells apoptosis through regulation of ROCK/Caspase 3 pathway, and caspase 3 activity was stimulated by miR-146a overexpression [23]. Overexpression of miR-146b-5P ( $\log 2=1.43)$ in glioma cell lines reduced cell proliferation and increased caspase-3/7 activity [24]. These results are consistent with the aforementioned protein analysis in this research.

In addition, some other regulations reported in literatures were also found in this experiment. For example, miR-21-5p was found to be significantly deregulated in colorectal cancer [25]; overexpression of miR-21-5p as a predictive marker for complete tumor regression to neoadjuvant chemo radiotherapy in rectal cancer patients [26]; overexpression of miR-638 inhibited the processes of tumor angiogenesis in vitro and in vivo [27]; miR-1246 was commonly upregulated in cancer cells by treatment with SAHA and DZNep and leading to apoptosis, cell cycle arrest and reduced migration of AGS and HepG2 cells [28]; miR-663a is upregulated by administration of the human cathelicidin AMP in the colon cancer cell line HCT-116, over-expression of miR-663a caused anti-proliferative effects both in vitro and in vivo [29].

Nevertheless, not all the miRNA regulations supported the inhibition, such as HCV-induced increase in miR-146a-5p expression both promotes viral infection and is relevant for pathogenesis of liver disease [30]; the low level of miR-615-5p increased the expression of RAB24 and facilitated HCC growth and metastasis in vitro and in vivo [31]; miR-31-5p was significantly upregulated for CIMP high colon carcinomas [32]. These have to be reviewed and further investigated to find the underling mechanism.

\section{MATERIALS AND METHODS}

\section{Materials and chemicals}

Steviol (99\% of purity, HPLC) was purchased from Sigma-Aldrich Co., Ltd. (Shanghai, China). 5-Fluorouracil (5-FU), dimethyl sulfoxide (DMSO), $\mathrm{Na}_{2} \mathrm{CO}_{3}, \mathrm{NaHCO}_{3}$, $\mathrm{NaCl}, \mathrm{KCl}, \mathrm{Na}_{2} \mathrm{HPO}_{4} \cdot 12 \mathrm{H}_{2} \mathrm{O}, \mathrm{NaH}_{2} \mathrm{PO}_{4} \cdot 2 \mathrm{H}_{2} \mathrm{O}$, EDTA 
disodium, dodecyl sodium sulfate (SDS), glycine, bromoxylenol blue, ammonium persulphate, tris (hydroxymethyl) methyl amino methane, ponceau, N,N,N, N-tetramethylethylenediamine (TEMED), xylene brilliant cyanin $\mathrm{G}$ (BS, G250), and phenylmethylsulfonyl fluoride (PMSF) were purchased from Sinopharm Chemical Reagent Co., Ltd. (Shanghai, China). TrypsinEDTA solution, propidium iodide (PI), triton X-100, endonuclease (RNase A), 3-(4,5-dimethylthiazol-2-yl)2,5-diphenyltetrazolium bromide (MTT), penicillinstreptomycin solution (100X), bovine albumin (BSA), BeyoECL Plus, polyvinylidene fluoride, RIPA lysis buffer, and 5,5',6,6'-tetrachloro-1,1',3,3'-tetraethylimidacarbocyasix iodide (JC-1) were purchased from Beyotime Biotechnology Co., Ltd. (Shanghai, China). DMEM medium, fetal bovine serum were purchased from Gibco Life Technologies Corporation (Carlsbad, CA, USA). Primary antibodies against p21, p53, cyclin D1, Bax, Bcl-2, caspase 3, $\beta$-actin, and horseradish peroxidase (HRP)-conjugated secondary antibodies were purchased from Cell Signal Technologies Inc. (Beverly, MA, USA). All other reagents were of analytical grade and used as received unless otherwise stated.

\section{Cell culture}

Cells involved in human digestion system were employed in this experiment. The human gastric cancer cell HGC-27, human colon adenocarcinoma cell Caco-2, human ileocecal adenocarcinoma epithelial cell HCT-8, human colorectal cell HCT 116, human gastric cancer cell MKN-45, and human poorly differentiated gastric cancer cell MGC-803 were purchased from Guangzhou Cellcook Biotech Co., Ltd. (Guangzhou, China). All of the cell lines were confirmed by STR. MKN-45 were cultured in RPMI 1640 medium, other cells were cultured in DMEM medium containing $10 \%$ fetal bovine serum, $1 \%$ glutamine (200 mmol/L), penicillin (100 IU/mL), and streptomycin $(100 \mathrm{mg} / \mathrm{L})$ in a humidified $5 \% \mathrm{CO}_{2}$ atmosphere at $37^{\circ} \mathrm{C}$ before use.

\section{MTT assay on cell proliferation}

Effect of steviol on the carcinoma cell proliferation was evaluated with MTT assay [37, 38]. The cells in logarithmic growth phase were digested with $0.25 \%$ trypsin and adjusted to 5000 cells/well using DMEM complete medium, respectively. Before steviol treatment, $100 \mu \mathrm{L}$ of the cell suspension was pipetted into each well in 96-well plates and cultured for $24 \mathrm{~h}$ at $37^{\circ} \mathrm{C}$ in $5 \% \mathrm{CO}_{2}$. Subsequently, cells were incubated with steviol at $37^{\circ} \mathrm{C}$ in $5 \% \mathrm{CO}_{2}$ for up to $48 \mathrm{~h}$. The culture medium was then removed and 100 $\mu \mathrm{L}$ of MTT reagent $(0.5 \mathrm{mg} / \mathrm{mL}$ in culture medium $)$ was added. After another $4 \mathrm{~h}$ of incubation, the MTT/ medium was removed and $150 \mu \mathrm{L}$ of DMSO was added to dissolve the formazan crystals. Absorbance of the solution was recorded at $570 \mathrm{~nm}$ to calculate the inhibition rate on cell growth. The control cell samples were prepared without steviol treatment, using same volume of culture medium to replace steviol while the other conditions remained same. Chemotherapy agent 5-fluorouracil (5-FU) was employed as the positive contrast. All measurements were performed in triplicate. The inhibition rate was calculated as following:

Cell growth inhibition rate $(\%)=\frac{\mathrm{A}_{570} \text { of control }-\mathrm{A}_{570} \text { of sample }}{\mathrm{A}_{570} \text { of control }} \times 100$

\section{Cell cycle analysis}

The cells were plated in 6 -well plate at $2 \times 10^{5} /$ well and treated with steviol. After $48 \mathrm{~h}$, the cells were then harvested with trypsin, washed, resuspended in cold PBS and fixed in cold $70 \%$ ethanol for storage at $-20^{\circ} \mathrm{C}$ overnight. Next, the cells were washed and resuspended in PBS containing $40 \mu \mathrm{g} / \mathrm{mL}$ PI and $0.1 \mathrm{mg} / \mathrm{mL}$ RNase, and then incubated for $30 \mathrm{~min}$ at room temperature. PI-stained cells were analyzed using flow cytometer and Mod Fit LT software.

\section{Mitochondrial membrane potential detection and Hoechst 33342 staining assay}

Mitochondrial membrane potential detection was conducted with the JC-1 assay. Briefly, after steviol treatment, cells were cultured in 24-well plates and incubated with JC-1 staining solution $(5 \mu \mathrm{g} / \mathrm{mL})$ for 20 $\min$ at $37^{\circ} \mathrm{C}$. Cells were then rinsed twice with $\mathrm{JC}-1$ staining buffer. Cells on chamber slides were scanned with fluorescence microscope.

Hoechst 33342 staining assay: The cells were seeded onto chamber slides in six-well plates at a density of $1 \mathrm{x}$ $10^{5}$ cells per well for $24 \mathrm{~h}$ of incubation. The cells were cultured in DMEM supplemented with $10 \%$ of FBS and incubated at $37^{\circ} \mathrm{C}$ in $5 \% \mathrm{CO}_{2}$. The medium was removed with replacement of new medium containing steviol, and cells were cultured for another $24 \mathrm{~h}$ at $37^{\circ} \mathrm{C}$ in $5 \% \mathrm{CO}_{2}$. After removal of the medium, the cells were washed with ice-cold PBS, and fixed with formalin (4\%, w/v). Cell nuclei were counterstained with Hoechst 33342 (10 mg/ $\mathrm{ml}$ in PBS) for $10 \mathrm{~min}$, and then observed and imaged by a fluorescence microscope.

\section{Determination of apoptotic percentage in cells}

Apoptotic percentage in cells was tested using Annexin V-FITC/PI double-labeled flow cytometry: The cells were plated in six-well plate at $2 \times 10^{5} /$ well and exposed to $0,50,100,200 \mu \mathrm{g} / \mathrm{mL}$ of steviol for 24 h. After $24 \mathrm{~h}$ of incubation, approximately $2 \times 10^{6}$ cells were collected, centrifuged, and resuspended in $100 \mu \mathrm{L}$ 
of Annexin binding buffer, then stained with Annexin V-FITC $(5 \mu \mathrm{L})$ and propidiumiodide (PI) $(1 \mu \mathrm{L})$ for $15 \mathrm{~min}$ of incubation at room temperature. Cells were detected with a FACS Calibur flow cytometer after adding $400 \mu \mathrm{L}$ of Annexin binding buffer.

\section{Western blot analysis}

Steviol treated cells were digested with $0.25 \%$ trypsin and $0.2 \%$ EDTA, washed with cold PBS for three times, suspended in ice-cold RIPA lysis buffer containing $1 \mathrm{mM}$ phenylmethane sulfonyl fluoride (PMSF) and incubated on ice for $30 \mathrm{~min}$. The suspension was then centrifuged at $12000 \mathrm{~g}$ for $5 \mathrm{~min}$ at $4^{\circ} \mathrm{C}$. The protein concentration of lysates was measured with Bradford method. Equivalent amounts of protein were separated by $10 \%$ sodium dodecyl sulfate-polyacrylamide gel electrophoresis (SDS-PAGE), and then transferred to a polyvinylidene difluoride (PVDF) membrane. Membranes were blocked for $1 \mathrm{~h}$ at room temperature using TBST containing $5 \% \mathrm{w} / \mathrm{v}$ non-fat milk, and probed with primary antibodies overnight at $4^{\circ} \mathrm{C}$ after washing. The membranes were incubated with secondary antibody for $1 \mathrm{~h}$ at room temperature. Protein bands were detected using the ChemiDoc imaging system (Bio-Rad, USA).

\section{miRNA profile and the statistics analysis}

Microarray assay was performed using a service provider (LC Sciences). tRNA was extracted using TRK-1001(LC Sciences, USA) for size fractionating to miRNA. An oligonucleotide tag was ligated to the poly (A) tail for later fluorescent dye staining. The microarray assay ( $\mu$ Paraflo ${ }^{\mathrm{TM}}$ MicroRNA microarray Assay) features, probe modification, tags and hybridization were described in the Supplementary Materials. Data were analyzed by first subtracting the background and then normalizing the signals using a LOWESS filter (Locally-weighted Regression). For the two color experiments, the ratio of the two sets of detected signals (log2 transformed, balanced) and p-values of the t-test were calculated; differentially detected signals were those with $\mathrm{p}$-values less than 0.01 .

\section{Statistical analysis}

Data were expressed as mean \pm SD. Multigroup comparisons of the means were carried out by one-way analysis of variance (ANOVA) test with post hoc contrasts by Student-Newman-Keuls test. All statistical analyses were performed using SPSS software. P values were two-tailed, and a value $\mathrm{P}<0.05$ was considered statistically significant.

\section{CONCLUSIONS}

The results indicate that steviol has an intensive inhibitory activity on six human gastrointestinal cancer cells with similar efficiency as 5-FU did at 100-200 $\mu \mathrm{g} / \mathrm{mL}$; it performed stronger cytotoxicity on the six cells at $250 \mu \mathrm{g} / \mathrm{mL}$ comparing to the performance of 5-FU. The inhibition mechanism follows mitochondrial apoptotic pathway, as evidenced by increase of Bax/ $\mathrm{Bcl}-2$ ratio, activation of $\mathrm{p} 21, \mathrm{p} 53$; and caspase 3 -independent mechanism is also involved. These results are consistent with the miRNA expression analysis. The steviol treated cancer cells presented remarkable miRNA regulation, such as miR-203a-3p $(\log 2=1.32)$, miR-6088 $(\log 2=-2.54)$ in HCT-116, $\operatorname{miR}-1268 b(\log 2=19.85), \operatorname{miR}-23 \mathrm{c}(\log 2=-2.05)$ in MKN-45. In view of the metabolic characteristics of steviol and its cytotoxicity on human cancer cells, steviol may become a potential chemotherapy agent for cancer treatment.

\section{Abbreviations}

5-FU, 5-fluorouracil; DOX, doxorubicin; CDDP, diammine dichloroplatinum; ADI, acceptable daily intake; LD 50, lethal dose 50\%; AMP, antimicrobial peptide; PI, propidium iodide; JC-1, 5,5',6,6'-tetrachloro-1,1',3,3'tetraethyl-imidacarbocyasix iodide; AIPC, androgenindependent prostate cancer; MTT, 3-(4,5-dimethylthiazol2-yl)-2,5-diphenyltetrazolium bromide; BSA, bovine albumin; DMEM, dulbecco's modified eagle medium. TP53INP1, tumor protein p53 inducible nuclear protein 1; TNFSF15, tumor necrosis factor (ligand) superfamily, member 15; TPD52, tumor protein D52; TNFRSF11A, tumor necrosis factor receptor superfamily, member 11a, NFKB activator; TUSC1, tumor suppressor candidate 1; ZNF, zinc finger protein; TP73, tumor protein $\mathrm{p} 73$; WT1, Wilms tumor 1; TPD52, tumor protein D52; ST7L, suppression of tumorigenicity 7 like; TUSC2, tumor suppressor candidate 2 .

\section{Author contributions}

J. M. Chen conducted to the concept, performed experiments and drafting the manuscript. X. C. Sui, Q. R. Peng, T.T. Zhang, J. Li, and J. Zhang performed experiments, contributed to the critical revision of the manuscript. Y. M. Xia contributed to the concept and design of the study, acquisition of data, analysis and interpretation of data, drafting the manuscript, critical revision of the manuscript, and final approval of the submitted manuscript.

\section{ACKNOWLEDGMENTS AND FUNDING}

Financial support from National Natural Science Foundation of China $(31772017,31371837)$, the national first-class discipline program of Light Industry Technology and Engineering (LITE2018-03), the freedom explore program of State Key Laboratory of Food Science and 
Technology, Jiangnan University (SKLF-ZZB-201808) and the project of outstanding scientific \& technological innovation group of Jiangsu Province are gratefully appreciated.

\section{CONFLICTS OF INTEREST}

The authors disclose no conflicts.

\section{REFERENCES}

1. Chen W, Zheng R, Baade PD, Zhang S, Zeng H, Bray F, Jemal A, Yu XQ, He J. Cancer statistics in China, 2015. CA Cancer J Clin. 2016; 66:115-32. https://doi.org/10.3322/ caac. 21338 .

2. Zhong BL, Li SH, Lv SY, Tian SL, Liu ZD, Li XB, Zhuang HQ, Tao R, Zhang W, Zhuo CJ. Suicidal ideation among Chinese cancer inpatients of general hospitals: prevalence and correlates. Oncotarget. 2017; 8:25141-25150. https:// doi.org/10.18632/oncotarget.15350.

3. Wang M, Lu J, Li J, Qi H, Wang Y, Zhang H. Steviol glucuronidation and its potential interaction with UDPglucuronosyltransferase 2B7 substrates. Food Chem Toxicol. 2014; 64:135-43. https://doi.org/10.1016/j. fct.2013.11.028.

4. Renwick AG, Tarka SM. Microbial hydrolysis of steviol glycosides. Food Chem Toxicol. 2008; 46:S70-74. https:// doi.org/10.1016/j.fct.2008.05.008.

5. Purkayastha S, Pugh G Jr, Lynch B, Roberts A, Kwok $\mathrm{D}$, Tarka SM Jr. In vitro metabolism of rebaudioside B, $\mathrm{D}$, and $\mathrm{M}$ under anaerobic conditions: comparison with rebaudioside A. Regul Toxicol Pharmacol. 2014; 68:25968. https://doi.org/10.1016/j.yrtph.2013.12.004.

6. Chen J, Wang X, Xia Y, Zhang J, Li J. The natural sweetener metabolite steviol inhibits human osteosarcoma cell line U2OS. Oncol Lett. 2018; 15:5250-5256.

7. Toskulkao C, Chaturat L, Temcharoen P, Glinsukon T. Acute toxicity of stevioside, a natural sweetener, and its metabolite, steviol, in several animal species. Drug Chem Toxicol. 1997; 20:31-44. https://doi. org/10.3109/01480549709011077.

8. EFSA ANS Panel (EFSA Panel on Food Additives and Nutrient Sources added to Food). Scientific Opinion on the safety of steviol glycosides for the proposed uses as a food additive. EFSA J. 2010; 8:1537. https://doi.org/10.2903/j. efsa.2010.1537.

9. Yoshikawa R, Kusunoki M, Yanagi H, Noda M, Furuyama JI, Yamamura T, Hashimoto-Tamaoki T. Dual antitumor effects of 5-fluorouracil on the cell cycle in colorectal carcinoma cells: a novel target mechanism concept for pharmacokinetic modulating chemotherapy. Cancer Res. 2001; 61:1029-37.

10. Osaki M, Tatebe S, Goto A, Hayashi H, Oshimura M, Ito H. 5-Fluorouracil (5-FU) induced apoptosis in gastric cancer cell lines: role of the p53 gene. Apoptosis. 1997; 2:221-26. https://doi.org/10.1023/A:1026476801463.

11. Li J, Hou N, Faried A, Tsutsumi S, Takeuchi T, Kuwano H. Inhibition of autophagy by 3-MA enhances the effect of 5-FU-induced apoptosis in colon cancer cells. Ann Surg Oncol. 2009; 16:761-71. https://doi.org/10.1245/ s10434-008-0260-0.

12. Qin LF, Ng IO. Induction of apoptosis by cisplatin and its effect on cell cycle-related proteins and cell cycle changes in hepatoma cells. Cancer Lett. 2002; 175:27-38. https:// doi.org/10.1016/S0304-3835(01)00720-0.

13. Zinkel S, Gross A, Yang E. BCL2 family in DNA damage and cell cycle control. Cell Death Differ. 2006; 13:1351-59. https://doi.org/10.1038/sj.cdd.4401987.

14. Murakami Y, Kawada N. MicroRNAs in hepatic pathophysiology. Hepatol Res. 2017; 47:60-69. https://doi. org/10.1111/hepr.12730.

15. Amirkhah R, Schmitz U, Linnebacher M, Wolkenhauer $\mathrm{O}$, Farazmand A. MicroRNA-mRNA interactions in colorectal cancer and their role in tumor progression. Genes Chromosomes Cancer. 2015; 54:129-41. https://doi. org/10.1002/gcc.22231.

16. Xiao J, Lv D, Zhou J, Bei Y, Chen T, Hu M, Zhou Q, Fu S, Huang Q. Therapeutic Inhibition of miR-4260 Suppresses Colorectal Cancer via Targeting MCC and SMAD4. Theranostics. 2017; 7:1901-13. https://doi.org/10.7150/ thno. 19168.

17. Tessitore A, Cicciarelli G, Mastroiaco V, Vecchio FD, Capece D, Verzella D, Fischietti M, Vecchiotti D, Zazzeroni F, Alesse E. Therapeutic Use of MicroRNAs in Cancer. Anticancer Agents Med Chem. 2016; 16:7-19. https://doi. org/10.2174/1871520615666150824153358.

18. Lewis BP, Burge CB, Bartel DP. Conserved seed pairing, often flanked by adenosines, indicates that thousands of human genes are microRNA targets. Cell. 2005; 120:15-20. https://doi.org/10.1016/j.cell.2004.12.035.

19. Grimson A, Farh KK, Johnston WK, Garrett-Engele P, Lim LP, Bartel DP. MicroRNA targeting specificity in mammals: determinants beyond seed pairing. Mol Cell. 2007; 27:91105. https://doi.org/10.1016/j.molcel.2007.06.017.

20. Friedman RC, Farh KK, Burge CB, Bartel DP. Most mammalian mRNAs are conserved targets of microRNAs. Genome Res. 2009; 19:92-105. https://doi.org/10.1101/ gr.082701.108.

21. Garcia DM, Baek D, Shin C, Bell GW, Grimson A, Bartel DP. Weak seed-pairing stability and high target-site abundance decrease the proficiency of 1sy- 6 and other microRNAs. Nat Struct Mol Biol. 2011; 18:1139-46. https://doi.org/10.1038/nsmb.2115.

22. Agarwal V, Bell GW, Nam JW, Bartel DP. Predicting effective microRNA target sites in mammalian mRNAs. elife. 2015; 4:e05005.

23. Xu B, Huang Y, Niu X, Tao T, Jiang L, Tong N, Chen S, Liu N, Zhu W, Chen M. Hsa-miR-146a-5p modulates 
androgen-independent prostate cancer cells apoptosis by targeting ROCK1. Prostate. 2015; 75:1896-903. https://doi. org/10.1002/pros.23068.

24. Wolter M, Werner T, Malzkorn B, Reifenberger G. Role of microRNAs Located on Chromosome Arm 10q in Malignant Gliomas. Brain Pathol. 2016; 26:344-58. https:// doi.org/10.1111/bpa.12294.

25. Kara M, Yumrutas O, Ozcan O, Celik OI, Bozgeyik E, Bozgeyik I, Tasdemir S. Differential expressions of cancer-associated genes and their regulatory miRNAs in colorectal carcinoma. Gene. 2015; 567:81-86. https://doi. org/10.1016/j.gene.2015.04.065.

26. Lopes-Ramos CM, Habr-Gama A, Quevedo BS, Felício NM, Bettoni F, Koyama FC, Asprino PF, Galante PA, Gama-Rodrigues J, Camargo AA, Perez RO, Parmigiani RB. Overexpression of miR-21-5p as a predictive marker for complete tumor regression to neoadjuvant chemoradiotherapy in rectal cancer patients. BMC Med Genomics. 2014; 7:68. https://doi.org/10.1186/ s12920-014-0068-7.

27. Cheng J, Chen Y, Zhao P, Liu X, Dong J, Li J, Huang C, $\mathrm{Wu}$ R, Lv Y. Downregulation of miRNA-638 promotes angiogenesis and growth of hepatocellular carcinoma by targeting VEGF. Oncotarget. 2016; 7:30702-30711. https:// doi.org/10.18632/oncotarget.8930.

28. Hibino S, Saito Y, Muramatsu T, Otani A, Kasai Y, Kimura M, Saito H. Inhibitors of enhancer of zeste homolog 2 (EZH2) activate tumor-suppressor microRNAs in human cancer cells. Oncogenesis. 2014; 3:e104. https://doi. org/10.1038/oncsis.2014.17.

29. Kuroda K, Fukuda T, Krstic-Demonacos M, Demonacos C, Okumura K, Isogai $\mathrm{H}$, Hayashi $\mathrm{M}$, Saito K, Isogai E. miR-663a regulates growth of colon cancer cells, after administration of antimicrobial peptides, by targeting CXCR4-p21 pathway. BMC Cancer. 2017; 17:33. https:// doi.org/10.1186/s12885-016-3003-9.

30. Bandiera S, Pernot S, El Saghire H, Durand SC, Thumann C, Crouchet E, Ye T, Fofana I, Oudot MA, Barths J, Schuster C, Pessaux P, Heim MH, et al. Hepatitis C virus-induced upregulation of microRNA miR-146a-5p in hepatocytes promotes viral infection and deregulates metabolic pathways associated with liver disease pathogenesis. J Virol. 2016; 90:6387-400. https://doi. org/10.1128/JVI.00619-16.

31. Chen Z, Wang X, Liu R, Chen L, Yi J, Qi B, Shuang Z, Liu M, Li X, Li S, Tang H. KDM4B-mediated epigenetic silencing of miRNA-615-5p augments RAB24 to facilitate malignancy of hepatoma cells. Oncotarget. 2017; 8:1771217725. https://doi.org/10.18632/oncotarget.10832.

32. Slattery ML, Herrick JS, Mullany LE, Wolff E, Hoffman MD, Pellatt DF, Stevens JR, Wolff RK. Colorectal tumor molecular phenotype and miRNA: expression profiles and prognosis. Mod Pathol. 2016; 29:915-27. https://doi. org/10.1038/modpathol.2016.73.

33. Tan S, Shi H, Ba M, Lin S, Tang H, Zeng X, Zhang X. miR-409-3p sensitizes colon cancer cells to oxaliplatin by inhibiting Beclin-1-mediated autophagy. Int J Mol Med. 2016; 37:1030-38. https://doi.org/10.3892/ijmm.2016.2492.

34. Pehserl AM, Ress AL, Stanzer S, Resel M, Karbiener M, Stadelmeyer E, Stiegelbauer V, Gerger A, Mayr C, Scheideler M, Hutterer GC, Bauernhofer T, Kiesslich T, Pichler M. Comprehensive analysis of miRNome alterations in response to sorafenib treatment in colorectal cancer cells. Int J Mol Sci. 2016; 17:2011. https://doi.org/10.3390/ ijms17122011.

35. Yang Y, Ma ZH, Li XG, Zhang WF, Wan J, Du LJ, Li GJ, Yang GK, Lu P. Iodine-125 irradiation inhibits invasion of gastric cancer cells by reactivating microRNA-181c expression. Oncol Lett. 2016; 12:2789-95. https://doi. org/10.3892/ol.2016.5033.

36. Kato K, Gong J, Iwama H, Kitanaka A, Tani J, Miyoshi H, Nomura K, Mimura S, Kobayashi M, Aritomo Y, Kobara H, Mori H, Himoto T, et al. The antidiabetic drug metformin inhibits gastric cancer cell proliferation in vitro and in vivo. Mol Cancer Ther. 2012; 11:549-60. https://doi. org/10.1158/1535-7163.MCT-11-0594.

37. Shen J, Park HS, Xia YM, Kim GS, Cui SW. The polysaccharides from fermented Ganoderma lucidum mycelia induced miRNAs regulation in suppressed HepG2 cells. Carbohydr Polym. 2014; 103:319-24. https://doi. org/10.1016/j.carbpol.2013.12.044.

38. Plumb JA. Cell sensitivity assays: the MTT assay. Methods Mol Med. 2004; 88:165-69. 